\title{
Hemolytic anemia due to hydrochlorothiazide: A case report
}

\author{
Özlem Seçen ${ }^{a, *}$, Ilgın Karaca ${ }^{\text {b }}$ \\ a Department of Cardiology, Elazig Training and Research Hospital, Elazig, Turkey \\ b Department of Cardiology, Firat University School of Medicine, Elazig, Turkey
}

\section{A R T I C L E I N F O}

\section{Article history:}

Received 6 April 2016

Received in revised form 6 June 2016

Accepted 7 June 2016

Available online 27 June 2016

\section{Keywords:}

Hemolytic anemia

Hydrochlorothiazide

Drug

\begin{abstract}
A B S T R A C T
Drug-associated hemolytic anemia is very rare. Hydrochlorothiazides are commonly used as diuretic or antihypertensive agents. In this report, we present an 80-year-old male patient who developed hemolytic anemia 20 days after using a combination of angiotensin receptor blocker and hydrochlorothiazide for the treatment of hypertension.

(c) 2016 The Society of Cardiovascular Academy. Production and hosting by Elsevier B.V. All rights reserved. This is an open access article under the CC BY-NC-ND license (http://creativecommons.org/licenses/by-nc-nd/4.0/).
\end{abstract}

\section{Introduction}

Autoimmune hemolytic anemia due to drugs is an immunologic condition characterized by the destruction of red blood cells induced by the antibodies that bind to the surface antigens of red blood cell membranes. ${ }^{1}$ Hydrochlorothiazides are commonly used diuretic or antihypertensive agents. While immune hemolytic anemia due to hydrochlorothiazide is rare, severe hemolytic anemia cases have been reported. In this study, we aimed to present a patient who had been taking hydrochlorothiazide for the treatment of hypertension and was thought to develop autoimmune hemolytic anemia due to the drug.

\section{Case report}

Eighty-year-old male patient admitted to the emergency unit for paleness, icterus of sclera, shortness of breath, weakness, fatigue, and chest pain that started 20 days ago and increased gradually. According to his medical history, he underwent aorto-coronary bypass surgery 15 years ago and had a stent implanted 3 years ago. ECG showed ST depression in derivations V1-V6. Troponin showed a normal level of $0.01 \mu \mathrm{g} / \mathrm{L}$. The patient was diagnosed with acute coronary syndrome and taken to the coronary intensive care unit where anti-ischemic therapy was started. His hemoglobin $(\mathrm{Hb})$ and hematocrit $(\mathrm{Hct})$ values were $7.5 \mathrm{~g} / \mathrm{dL}$ (normal range: 13.2-17.4 $\mathrm{g} / \mathrm{dL}$ ) and 21\% (normal range:

\footnotetext{
* Corresponding author at: Department of Cardiology, Elazig Training and Research Hospital, Rızaiye Mah, İnönü Cad, No. 74, Elazig, Turkey. Tel.: +90 42423810 00; fax: + 904242121461 .

E-mail address: ozllemsecen@hotmail.com (Ö. Seçen).

Peer review under responsibility of The Society of Cardiovascular Academy.
}

39-51\%), respectively. Of the erythrocyte indices, mean corpuscular volume (MCV) was $100 \mathrm{fL}$ (normal range: 76-96 fL), mean corpuscular hemoglobin (MCH) was $23.6 \mathrm{pg} / \mathrm{cells}$ (normal range: $27-33 \mathrm{pg} / \mathrm{cells}$ ), and mean corpuscular hemoglobin concentration (MCHC) was $27.1 \mathrm{~g} / \mathrm{dL}$ (normal range: 30-35.5 g/dL). Fragmented normochromic red blood cells and anisocytosis were seen in the peripheral blood smear. Reticulocyte rate was found as $3 \%$. In addition, thrombocyte count was $211 \times 10^{3} / \mu \mathrm{L}$ (normal range: $150-450 \times 10^{3} / \mu \mathrm{L}$ ). Biochemical parameters were as follows: blood urea nitrogen $90 \mathrm{mg} / \mathrm{dL}$ (normal range: $10-$ $50 \mathrm{mg} / \mathrm{dL}$ ), serum creatinine $1.1 \mathrm{mg} / \mathrm{dL}$ (normal range: $0.6-1.2 \mathrm{mg} / \mathrm{dL}$ ), and serum sodium $136 \mathrm{mmol} / \mathrm{L}$ (normal range: $135-145 \mathrm{mmol} / \mathrm{L}$ ) and potassium $4.8 \mathrm{mmol} / \mathrm{L}$ (normal range: $3.5-5.1 \mathrm{mmol} / \mathrm{L}$ ). Of coagulation tests, prothrombin time (PT) was $13 \mathrm{~s}$ (normal range: 11-14 s), the reference range for international normalized ratio (INR) was 1.15 (normal range: 0.8-1.2), and activated partial thromboplastin time (aPTT) was $27.6 \mathrm{~s}$ (normal range: $21-36 \mathrm{~s}$ ).

One unit of red blood cell suspension was given. $\mathrm{Hb}$ and Htc levels were increased to $9.6 \mathrm{~g} / \mathrm{dL}$ and $24.6 \%$, respectively; and then to $10.7 \mathrm{~g} / \mathrm{dl}$ and $26.8 \%$, respectively, following the administration of a second suspension of red blood cells. Vitamin B12 level was normal, folic acid level was low and ferritin level was high which were $242 \mathrm{pg} / \mathrm{mL}$ (normal range: 191-663 pg/mL), $4.5 \mathrm{ng} / \mathrm{mL}$ (normal range: 4.6-18.7 ng/mL) and $1080 \mathrm{ng} / \mathrm{mL}$ (normal range: $30-400 \mathrm{ng} / \mathrm{mL}$ ), respectively. Control complete blood count values at day 2 were $8.5 \mathrm{~g} / \mathrm{dL}$ for $\mathrm{Hb}$ and $22.1 \%$ for Hct. Consultation was requested from internal medicine department. Occult blood test in the stool was negative. Endoscopy was performed to exclude gastrointestinal bleeding. Thus, active gastrointestinal hemorrhage was excluded. Abdominal ultrasound revealed no intra-abdominal hematoma, mass, or hepatomegaly or splenomegaly. Indirect Coombs test was negative, but direct Coombs was positive as $\operatorname{IgG}+2$. Lactate dehydrogenase (LDH) was increased to $741 \mathrm{U} / \mathrm{L}$ (normal 
range: $240-480 \mathrm{U} / \mathrm{L}$ ). Haptoglobin was $<0.3 \mathrm{~g} / \mathrm{L}$ (normal range: $0.3-$ $2 \mathrm{~g} / \mathrm{L}$ ). Yes, total bilirubin and direct bilirubin levels were high which were $2.6 \mathrm{mg} / \mathrm{dL}$ (normal range: $0-1.2 \mathrm{mg} / \mathrm{dL}$ ) and $1.1 \mathrm{mg} / \mathrm{dL}$ (normal range: $0-0.3 \mathrm{mg} / \mathrm{dL}$ ), respectively. Urine analysis revealed proteinuria, and $(+)$ bilirubin and $(+++)$ hemoglobin. ANA serum dilution was negative. It was understood from his medical records that hemoglobin and Hct levels were $13.1 \mathrm{~g} / \mathrm{dL}$ and 38.7\%, respectively, 20 days ago. When his medical history was reviewed, it was seen that he was started on daily irbesartan $150 \mathrm{mg}$ plus hydrochlorothiazide $12.5 \mathrm{mg}$ for high blood pressure. The patient was then transferred to internal medicine clinic with the current findings for hemolytic anemia due to thiazide. Then, hydrochlorothiazide was stopped. After that, trandolapril was started for treatment of hypertension. The patient was put on followup program with periodic complete blood count analysis. At the end of the next following 2 weeks, a negative Coombs test result and a hemoglobin value of $10.5 \mathrm{~g} / \mathrm{dL}$ were obtained. During follow-up, the hemoglobin values were $13.1 \mathrm{~g} / \mathrm{dL}$ and $13.3 \mathrm{~g} / \mathrm{dL}, 1$ month later and 3 months later, respectively.

\section{Discussion}

Drug-associated hemolytic anemia is seen approximately in one out of a million individual. It may be lethal, possibly with no diagnosis established. ${ }^{2}$ It was found out in 2007 that up to 125 different drugs may cause hemolysis. ${ }^{3}$ Forty years ago, back when methyldopa and antibiotics like high doses of intravenous penicillin had been used commonly, most of the reported cases of hemolytic anemia were due to the use of these agents. Today, however, cases of hemolytic anemia are rather associated with cephalosporins since methyldopa is almost no more used and second- and third-generation cephalosporins are the leading antibiotics. ${ }^{4,5}$

Hemolytic anemia associated with drugs occurs through one of three basic mechanisms ${ }^{6-9}$ : (i) drug absorption mechanism, where antibodies against the drug react with the adsorbed drug on the surface of red blood cell membrane. The antibody-antigen complex that is formed on the surface of red blood cell membrane is removed from the circulation by reticulo-endothelial system, thus resulting in extravascular hemolysis; (ii) immune complex mechanism, in which drug-antibody complex binds to the red blood cell membrane activating the complement cascade; this process leads to acute intravascular hemolysis; and (iii) auto-antibody type, in which antibodies against the drug bind to red blood cell membrane through cross reaction resulting in extravascular hemolysis (Table 2). (See Table 1.)

Anemia associated with hydrochlorothiazide is an example of immune complex-type immune hemolytic anemias. Intravascular hemolysis develops as a result of activation of complement system by the binding of the drug to the red blood cell membrane and may be severe and fatal. Anemia, fragmented red blood cells on peripheral smear, hyperbilirubinemia, increased levels of LDH, reticulocytosis, positive Coombs test, hemoglobinuria and findings related with organ failures may be observed depending on the severity of hemolysis. ${ }^{5}$ In our case, an immune event was considered since anemia, weakness and

Table 1

Laboratory values of the patient.

\begin{tabular}{|c|c|c|c|c|c|c|}
\hline & $\mathrm{Hb}$ & Hct & RBCs & Total bil. & Direct bil. & LDH \\
\hline Day & $(\mathrm{g} / \mathrm{dL})$ & $\%$ & $\overline{10^{6} / \mu \mathrm{L}}$ & (mg/dL) & $(\mathrm{mg} / \mathrm{dL})$ & $(\mathrm{U} / \mathrm{L})$ \\
\hline $20 \mathrm{~d}$ ago & 3.1 & 38 & 4.00 & 0.35 & 0.35 & 294 \\
\hline Day 1 & 7.5 & 21 & 2.07 & 1.54 & 0.70 & 322 \\
\hline Day 2 & 9.6 & 26.8 & 2.41 & & & \\
\hline Day 3 & 10.7 & 26.8 & 2.69 & & & 255 \\
\hline Day 4 & 8.5 & 22.1 & 2.18 & 2.99 & 1.14 & 347 \\
\hline Day 5 & 9.5 & 24.2 & 2.40 & 2.46 & 741 & \\
\hline $3 \mathrm{~m}$ later & 13.3 & 40.5 & 3.87 & 0.55 & 0.21 & 382 \\
\hline
\end{tabular}

Hb: hemoglobin; Htc: hematocrit; RBCs: red blood cells; Bil: bilirubin; LDH: lactate dehydrogenase; d: days; m: months.
Table 2

Mechanism of drugs that cause immune hemolytic anemia.

\begin{tabular}{|c|c|c|c|}
\hline Mechanism & $\begin{array}{l}\text { Drug absorption } \\
\text { (Hapten) }\end{array}$ & Immune complex & Auto-antibody \\
\hline DAT & Positive anti-IgG & Positive anti-C3 & Positive anti-IgG \\
\hline $\begin{array}{l}\text { Location of } \\
\text { hemolysis }\end{array}$ & Extravascular & Intravascular & Extravascular \\
\hline Drug & $\begin{array}{l}\text { Penicillin } \\
\text { Ampicillin } \\
\text { Methicillin } \\
\text { Carbenicillin } \\
\text { Cephalothin } \\
\text { Cephalordin }\end{array}$ & $\begin{array}{l}\text { Quinidine } \\
\text { Phanecetin } \\
\text { Hydrochlorothiazide } \\
\text { Rifampin } \\
\text { Sulfonamide } \\
\text { Isoniazid } \\
\text { Insulin } \\
\text { Tetracycline } \\
\text { Melphalan } \\
\text { Acetaminophen } \\
\text { Hydralazine } \\
\text { Probenecid } \\
\text { Chlorpromazine } \\
\text { Streptomycin } \\
\text { Fluorouracil } \\
\text { Sulindac }\end{array}$ & $\begin{array}{l}\text { Alpha-methyldopa } \\
\text { Mefenamic acid } \\
\text { L-Dopa } \\
\text { Procainamide } \\
\text { Ibuprofen } \\
\text { Diclofenac } \\
\text { Interferon Alpha }\end{array}$ \\
\hline
\end{tabular}

DAT: direct antiglobulin test.

shortness of breath were gradually increased after hydrochlorothiazide was started with the absence of an anemia 20 days ago, accompanied by the fall in hemoglobin values following the administration of red blood cell suspensions and a positive Coombs test. Presence of fragmented red blood cells, hyperbilirubinemia, hemoglobinuria and decreased levels of haptoglobin $(<0.3$, normal range over the age of $50: 0.47-2.1 \mathrm{~g} / \mathrm{L})$ were among findings that demonstrated an intravascular hemolysis in our case.

In practice, Coombs test is used to investigate and diagnose these types of hemolysis. This test is a laboratory method used to identify the presence of incomplete antibodies attached to the red blood cells or circulating freely and is also known as antiglobulin test. ${ }^{10}$ Positive direct Coombs test may indicate a hemolysis that develops through an immune complex-type reaction. In our case, polyspecific direct Coombs test IgG was positive and indirect Coombs test was negative.

In 1976, Vila et al. ${ }^{11}$ had observed, for the first time, the episodes in a 67-year-old patient whom they treated with a combination of methyldopa and hydrochlorothiazide for hypertension during 4 years and associated the mild to moderate hemolytic anemia with the thiazide fraction of the medication. In 1980, Garratty et al. ${ }^{12}$ observed a severe immune hemolytic anemia and renal failure in a 24 -year-old black patient who ingested 15-20 tablets of methyldopa plus hydrochlorothiazide to commit suicide. They associated the hemolytic anemia with the antibodies associated with hydrochlorothiazide through immune complex mechanism. In these two cases of intravascular hemolysis, antibodies were developed against hydrochlorothiazide but not against methyldopa. In 1986, Shirey et al. ${ }^{13}$ considered hemolytic anemia due to a drug when direct antiglobulin tested positive in a 53-year-old black female. They found similar antibodies against diuretics by characterizing hydrochlorothiazide antibody in serologic studies and offered an alternate diuretic therapy for patients.

Mortality is reported to be $40 \%$ when hemolytic anemia associated with drugs is assessed where hemolytic anemia due to ceftriaxones is associated with higher mortality among them. ${ }^{5}$ Beck et al. ${ }^{14}$ observed a case of hemolytic anemia in a 53-year-old black male patient 18 months after starting hydrochlorothiazide and methyldopa. It was the first case that ended up with death after hemolytic anemia due to hydrochlorothiazide. The patient had a positive direct and indirect Coombs test, a low level of haptoglobin of $0.5 \mathrm{~g} / \mathrm{dL}$ and a high LDH in whom cause of death could not be established in autopsy but was considered as fatal immune hemolytic anemia associated with the use of hydrochlorothiazide.

Anemia may sometimes immediately be demonstrated by serious clinical findings while the diagnosis may be delayed as long as 
1-2 weeks after the intake of the drug in cases without a serious hemolysis, and anemia may be associated with other causes without any established diagnosis. ${ }^{15}$ In our patient, a moderate anemia accompanied by a mild increase in LDH levels and positive Coombs test were found 20 days after the intake of the drug since the hemolysis was not severe.

Cessation of the drug in mild cases and steroids plus supportive care in more severe cases are recommended. ${ }^{16,17}$ In our patient, the moderate anemia was recovered without any treatment after stopping hydrochlorothiazide.

The diagnosis of hemolytic anemia associated with drugs was established in our patient based on medical history and clinical signs and symptoms. Presence of fragmented red blood cells and hemoglobinuria suggested an intravascular hemolysis.

\section{References}

1. Neff AT. Autoimmune hemolytic anemias. In: Greer JP, Foerster J, Lukens JN, Rodgers GM, Paraskevas F, Glader B, editors. Wintrobe's Clinical Hematology, 2nd ed., vol. 2. Philadelphia: Lippincott; 2004. p. 1157-1182.

2. Petz LD, Garratty G. Immune Hemolytic Anemia. 2nd ed. Philadelphia, PA: Churchill Livingstone; 2004

3. Garratty G, Arndt PA. An update on drug-induced immune hemolytic anemia Immunohematology 2007;23:105-119.

4. Garratty G. Drug-induced immune hemolytic anemia-the last decade. Immunohematology 2004;20:38-46.
5. Bradley CG, Richard CF. Autoimmune hemolytic anemia. Am J Hematol 2002;69: 258-271.

6. Garratty G. Immune cytopenia associated with antibiotics. Transfus Med Rev 1993;7: 255-267.

7. Pirmohamed M, Breckenridge AM, Kitteringham NR, Park BK. Adverse drug reactions. BMJ 1998;316:1295-1298.

8. Candemir M, Polat A, Kılıç İ, Balcı YI, İnan M, Halis H. Sefalosporinlerle ilişkili otoimmün hemolitik anemi. Cocuk Sağlığı ve Hastalklan Dergisi 2006;49:315-318.

9. Schwartz RS, Berkman EM, Silberstein LE. Autoimmune hemolytic anemias. In: Hoffman R, Benz Jr EJ, Shattil SJ, Furie B, Cohen HJ, Silberstein LE, et al, editors. Hematology: Basic Principles and Practice. 3d ed. Philadelphia: Churchill Livingstone; 2000. p. 624.

10. Handin RI, Lux IV SE, Stossel TP, editors. Blood: Principles and Practice of Hematology. 2nd ed. Philadelphia, PA. USA: Lippincott, Williams and Wilkins; 2003.

11. Vila JM, Blum L, Dosik H. Thiazide induced hemolytic anemia. JAMA 1976;236:1723.

12. Garratty G, Houston M, Petz LD, Webb M. Acute immune intravascular hemolysis due to hydrochlorothiazide. Am J Clin Pathol 1981 Jul;76(1):73-78.

13. Shirey RS, Bartholomew J, Bell W, Pollack B, Kickler TS, Ness PM. Characterization of antibody and selection of alternative drug therapy in hydrochlorothiazide-induced immune hemolytic anemia. Transfusion 1988 Jan-Feb;28(1):70-72.

14. Beck ML, Cline JF, Hardman JT, Racela LS, JW D. Fatal intravascular immune hemolysis induced by hydrochlorothiazide. Am J Clin Pathol 1984 Jun;81(6):791-794.

15. Arndt PA, Lager RM, Gratty G. Serology of antibodies to second- and third-generation cephalosporins associated with immune hemolytic anemia and/or positive direct antiglobulin test. Immunohematology 1999;39:1239-1246.

16. Citak A, Garratty G, Ücsel R, Karaböcüoğlu M, Uzel N. Ceftriaxone-induced haemolytic anemia in a child with no immune deficiency or haematological disease. J Paediatr Child Health 2002;38:209-210.

17. Seltsam A, Salama A. Ceftriaxone-induced immune haemolysis: two case reports and a concise review of the literature. Intensive Care Med 2000;26:1390-1394. 